\title{
Postpartum health related quality of life: relationship to antenatal exercise practice in a Nigerian population
}

\section{Chidiebele P. Ojukwu' ${ }^{1 *}$, Adaora J. Okemuo', Emelie M. Anekwu², Obianuju G. Okeke', Chioma N. Ikele ${ }^{1}$, Chigozie I. Uchenwoke ${ }^{1}$}

${ }^{1}$ Department of Medical Rehabilitation, University of Nigeria, Enugu Campus, Enugu State, Nigeria

${ }^{2}$ Department of Physiotherapy, Federal Teaching Hospital, Abakaliki, Ebonyi State, Nigeria

Received: 23 April 2018

Accepted: 23 May 2018

\author{
*Correspondence: \\ Dr. Chidiebele P Ojukwu, \\ E-mail: chidiebele.ojukwu@unn.edu.ng
}

Copyright: (C) the author(s), publisher and licensee Medip Academy. This is an open-access article distributed under the terms of the Creative Commons Attribution Non-Commercial License, which permits unrestricted non-commercial use, distribution, and reproduction in any medium, provided the original work is properly cited.

\begin{abstract}
Background: Antenatal exercise (ANE) has been reported to improve postpartum health outcomes in women. However, postpartum health related outcomes of ANE have been inconsistent in previous studies and have not been studied in a Nigerian population. This study assessed the influence of ANE on postpartum health-related quality of life (HRQOL) of Nigerian women.

Methods: 350 purposively selected women participated in this cohort study. During the last two pregnancy trimesters, participants completed a questionnaire assessing ANE practice/pattern while the Short Form (SF-36) questionnaire was used to assess HRQOL during postpartum. Data were analyzed using descriptive and inferential statistics with alpha level set at 0.05 .

Results: Majority $(82.9 \%)$ of the women practiced ANE. Women who did not exercise showed significantly ( $\mathrm{p}=$ 0.001) higher general health scores than those who did not. Women who exercised for <30 mins also showed significantly $(\mathrm{p}=0.040)$ higher general health scores, as compared to those who exercised for $\geq 30$ mins. HRQOL was negatively correlated with each of practice and duration of ANE.

Conclusions: It was concluded that ANE practice and patterns did not improve postpartum HRQOL. Improved education and supervision of ANE is recommended for improved postpartum health outcomes.
\end{abstract}

Keywords: Antenatal exercise, Duration, Frequency, Health related quality of life, Nigeria, Postpartum

\section{INTRODUCTION}

Exercise has undoubtedly become a vital aspect of women's lives and an important part of antenatal and postnatal care in most settings. ${ }^{1}$

Practice of antenatal exercise (ANE) has been widely recommended and is recognized a safe practice for both mother and foetus, provided the intensity, duration and frequency of exercise are tailored to the requirements of each woman. ${ }^{1-5}$ Several benefits have been associated with positive ANE practices during the childbearing years and beyond. Such benefits include improvement of physical fitness and cardiovascular endurance, prevention of excessive gestational weight gain and glucose intolerance, decrease in occurrence of common pregnancy problems and improvement in psychological adjustments to changes in pregnancy, reduction of postpartum recovery period, among others. ${ }^{6-8}$ Reduction of pregnancy-related complications in response to ANE practices has also been shown to affect postpartum health status in women. ${ }^{1,9,10}$

Pregnancy and postpartum periods have been associated with physical changes, mental health problems, including stress, anxiety, depression and psychosis as well as changes in women's quality of life (QOL). ${ }^{11-13}$ Some 
pregnancy complications last into the postpartum period while others specifically commence during postpartum. Exercise prior to, during and after pregnancy has been associated with improved health status in women within the respective periods and beyond. ${ }^{3,13-16}$ Campaigns on ANE practices have emphasized its benefits on postpartum recovery and health status although only few empirical evidences are available to support the impact of ANE on postpartum health status. However, the results of the available studies are controversial. In some studies, ANE was related to improved postpartum QOL, wellbeing and reduction of postpartum depression, while in others there were no associations between ANE and postpartum health status. ${ }^{17-24}$ In developing countries like Nigeria, empirical evidences are scarce on the impact of practice and/or patterns of ANE on postpartum health status of nursing mothers. There is need to evaluate the practice and patterns of ANE in mothers as well as how these antenatal health behaviours relate with postnatal health status. This information may stimulate modifications in the provision of effective interventions to enhance women's antenatal and postpartum health related QOL. This study was therefore designed to determine the influence of ANE on postpartum healthrelated QOL.

\section{METHODS}

Three hundred and fifty (350) consenting women who were purposively recruited from the antenatal clinics of eight hospitals in Enugu, Nigeria participated in this longitudinal cohort study. The hospitals were randomly selected from urban and rural areas to provide socioeconomic and geographical diversity and included four public and four private hospitals. Women were eligible to participate in the study if they:

1) registered for and received prenatal care at one of the selected hospitals and planned to give birth at one of these hospitals

2) were within the age range of 18-35 years

3) spoke and understood English or Igbo

4) were in their second gestational trimester at the time of recruitment

5) could be contacted by telephone, and

6) had no known mental health issues that could affect their memory capabilities.

Each participant gave a written informed consent prior to participation in the study. On recruitment during the respective women's second gestational trimesters, they were asked to complete either an English or Igbo version of a modified questionnaire adapted from a previous study. ${ }^{25}$ This instrument sought information on sociodemographic, maternal and obstetric characteristics as well as practice and pattern of antenatal exercises (ANE). A follow-up survey, using the same questionnaire was conducted in the third trimesters, respectively (Figure 1).
Six weeks post-partum, participants who were eligible to complete the study (Figure 1) completed the SF-36 questionnaire comprising eight score domains, including, vitality, physical functioning, bodily pain, general health perceptions, and physical role functioning, emotional role functioning, social role functioning and mental health. ${ }^{26-28}$

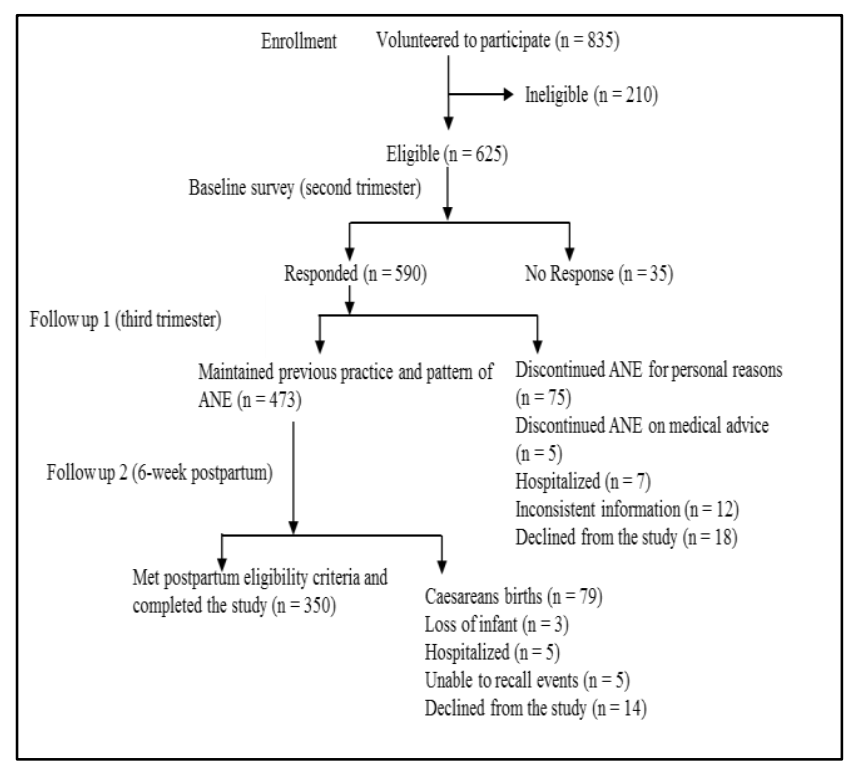

Figure 1: Sampling flow chart.

\section{Data Analysis}

Descriptive statistics of mean, standard deviation, frequencies and percentages were used to summarize data. Inferential statistics of Independent T-test was used to test for statistical differences between variables while Spearman rank correlation order were used to test the correlations between exercise practice and each of the QOL domains. Alpha level was set at 0.05. Data was analyzed using SPSS version 21.

\section{RESULTS}

Table 1 shows the socio-demographic characteristics of the participants. Majority of the women were above 25 years $(75.1 \%)$, Christians $(97.7 \%)$, self-employed $(43.1 \%)$, married $(94.3 \%)$ and urban dwellers $(61.7 \%)$.

A greater percentage of the women had monogamous family settings (88.3\%), university degree(s) (52.7\%) and earned $<\mathrm{N} 18,000.00$ (approximately 28 - 56 US dollars) monthly.

Participants' maternal and obstetrics characteristics are presented on Table 2. Majority of the women were multigravida $(70.3 \%)$, multiparous $(68.3 \%)$, had more than one child $(66.6 \%)$ and commenced antenatal care in their second gestational trimester $(68.6 \%)$. Antenatal exercise (ANE) practices of the participants are presented on Table 3. 
Table 1: Socio-demographic characteristics of the participants $(\mathbf{N}=\mathbf{3 5 0})$.

\begin{tabular}{|c|c|c|}
\hline Variables & Frequencies & Percentage \\
\hline \multicolumn{3}{|l|}{ Age (years) } \\
\hline$<25$ & 87 & 24.9 \\
\hline$>25$ & 263 & 75.1 \\
\hline \multicolumn{3}{|l|}{ Religion } \\
\hline Christianity & 342 & 97.8 \\
\hline Islam & 4 & 1.1 \\
\hline Traditional & 4 & 1.1 \\
\hline \multicolumn{3}{|l|}{ Occupation } \\
\hline Unemployed & 114 & 32.6 \\
\hline Self-employed & 151 & 43.1 \\
\hline Public servant & 85 & 24.3 \\
\hline \multicolumn{3}{|l|}{ Education } \\
\hline None & 10 & 2.9 \\
\hline Basic education & 25 & 7.1 \\
\hline O’level degree & 127 & 36.3 \\
\hline University degree(s) & 188 & 53.7 \\
\hline \multicolumn{3}{|c|}{ Monthly Income (Naira) } \\
\hline$<18,000$ & 263 & 75.1 \\
\hline$>18,000$ & 87 & 24.9 \\
\hline \multicolumn{3}{|l|}{ Family Setting } \\
\hline Polygamy & 36 & 10.3 \\
\hline Monogamy & 309 & 88.3 \\
\hline Single parenting & 7 & 2.0 \\
\hline Unspecified & 2 & 0.6 \\
\hline \multicolumn{3}{|l|}{ Marital Status } \\
\hline Single & 15 & 4.3 \\
\hline Married & 330 & 94.3 \\
\hline Divorced & 2 & 0.6 \\
\hline Widowed & 3 & 0.9 \\
\hline \multicolumn{3}{|l|}{ Residence } \\
\hline Urban & 216 & 61.7 \\
\hline Rural & 134 & 38.3 \\
\hline
\end{tabular}

Table 2: Maternal and obstetric characteristics of participants $(\mathrm{N}=350)$.

\begin{tabular}{|c|c|c|}
\hline Variables & Frequencies & Percentage \\
\hline \multicolumn{3}{|l|}{ Gravidity } \\
\hline Primigravida & 104 & 29.7 \\
\hline Multigravida & 246 & 70.3 \\
\hline \multicolumn{3}{|l|}{ Parity } \\
\hline Primiparous & 111 & 31.7 \\
\hline Multiparous & 239 & 68.3 \\
\hline \multicolumn{3}{|c|}{ Number of children } \\
\hline 1 & 117 & 33.4 \\
\hline$>1$ & 233 & 66.6 \\
\hline \multicolumn{3}{|c|}{ Commencement of antenatal care (trimester) } \\
\hline First & 110 & 31.4 \\
\hline Second & 240 & 68.6 \\
\hline
\end{tabular}

Table 3: Practice and patterns of antenatal exercise among the participants.

\begin{tabular}{|c|c|c|}
\hline Variables & Frequency & Percentage \\
\hline \multicolumn{3}{|c|}{ Practice of antenatal exercise $(n=350)$} \\
\hline Yes & 290 & 82.9 \\
\hline No & 60 & 17.1 \\
\hline \multicolumn{3}{|c|}{ Patterns of antenatal exercise $(n=290)$} \\
\hline \multicolumn{3}{|c|}{ Type of exercises practiced } \\
\hline Aerobics & 221 & 76.2 \\
\hline Abdominals & 19 & 6.6 \\
\hline Pelvic floor & 17 & 5.9 \\
\hline Back care & 14 & 4.8 \\
\hline Swimming & 1 & 0.3 \\
\hline Cycling & 2 & 0.7 \\
\hline Stretching & 7 & 2.4 \\
\hline Relaxation & 4 & 1.4 \\
\hline Muscle strengthening & 5 & 1.7 \\
\hline \multicolumn{3}{|c|}{ Duration (minutes per day) } \\
\hline$<30$ & 106 & 36.6 \\
\hline$\geq 30$ & 184 & 63.4 \\
\hline \multicolumn{3}{|c|}{ Frequency (days per week) } \\
\hline$<5$ & 203 & 70.0 \\
\hline$\geq 5$ & 87 & 30.0 \\
\hline \multicolumn{3}{|c|}{ Prescribers of antenatal exercise } \\
\hline Doctor & 14 & 4.8 \\
\hline Nurse/midwife & 76 & 26.2 \\
\hline Physiotherapist & 8 & 2.8 \\
\hline Self & 113 & 39.0 \\
\hline Non-clinical personnel & 79 & 27.2 \\
\hline
\end{tabular}

Most $(82.9 \%)$ of the participants practiced ANE, particularly aerobic exercises $(76.2 \%)$. Majority exercised for less than five days weekly $(70.0 \%)$ and $\geq 30$ minutes daily $(63.4 \%)$. A greater percentage $(39.0 \%)$ of the participants exercised based on self-prescription.

The independent t-test results showing differences in the participants' Health-Related Quality of Life based on practice and patterns of ANE are presented on table 4. In relation to practice of ANE, there was a significant ( $\mathrm{p}=$ $0.001)$ difference in the general health $(\mathrm{GH})$ of women who exercised and those who did not.

There was also a significant $(\mathrm{p}=0.040)$ difference in the general health $(\mathrm{GH})$ of women who exercised for $<30$ mins daily and those who exercised for $\geq 30$ minutes daily.

Table 5 shows the correlations between participants' health-related quality of life and each of practice of and patterns of ANE.

Participants' general health $(\mathrm{GH})$ correlated with practice of ANE ( $p=0.003)$ as well as with duration of ANE exercise $(p=0.015)$. However, frequency of ANE showed no significant correlation with any of the HRQOL domains. 
Table 4: Independent t-test results showing differences in the participants' health-related quality of life based on practice and patterns of antenatal exercises.

\begin{tabular}{|c|c|c|c|c|c|c|c|c|}
\hline \multirow[t]{2}{*}{$\begin{array}{l}\text { Categorical distribution } \\
\text { based on practice and } \\
\text { pattern of ANE }\end{array}$} & \multicolumn{8}{|c|}{ Health-related quality of life } \\
\hline & PF & RLPH & RLEP & EF & EWP & SF & PAIN & GH \\
\hline \multicolumn{9}{|l|}{ Practice of ANE } \\
\hline Yes $(n=290)$ & $\begin{array}{l}96.18 \\
\pm 55.81\end{array}$ & $\begin{array}{l}84.79 \\
\pm 33.15\end{array}$ & $\begin{array}{l}89.27 \\
\pm 29.71\end{array}$ & $\begin{array}{l}76.59 \\
\pm 17.97\end{array}$ & $\begin{array}{l}86.48 \\
\pm 12.33\end{array}$ & $\begin{array}{l}89.77 \\
\pm 19.54\end{array}$ & $\begin{array}{l}84.20 \\
\pm 23.58\end{array}$ & $\begin{array}{l}83.99 \\
\pm 12.83\end{array}$ \\
\hline No $(n=60)$ & $\begin{array}{l}95.80 \\
\pm 13.61\end{array}$ & $\begin{array}{l}88.33 \\
\pm 30.58\end{array}$ & $\begin{array}{l}88.34 \\
\pm 30.58\end{array}$ & $\begin{array}{l}81.33 \\
\pm 17.97\end{array}$ & $\begin{array}{l}83.80 \\
\pm 14.34\end{array}$ & $\begin{array}{l}91.96 \\
\pm 17.12\end{array}$ & $\begin{array}{l}86.50 \\
\pm 23.26\end{array}$ & $\begin{array}{l}89.17 \\
\pm 9.87\end{array}$ \\
\hline t-value & -0.052 & 0.768 & -0.220 & 1.861 & -1.489 & 0.805 & 0.690 & 3.494 \\
\hline p-value & 0.958 & 0.443 & 0.826 & 0.064 & 0.134 & 0.421 & 0.491 & $0.001 *$ \\
\hline \multicolumn{9}{|c|}{ Duration of ANE (minutes) } \\
\hline$<30(\mathrm{n}=106)$ & $\begin{array}{l}93.81 \\
\pm 18.03\end{array}$ & $\begin{array}{l}84.92 \\
\pm 2.14\end{array}$ & $\begin{array}{l}85.16 \\
\pm 2.80\end{array}$ & $\begin{array}{l}79.70 \\
\pm 19.63\end{array}$ & $\begin{array}{l}87.39 \\
\pm 1.64\end{array}$ & $\begin{array}{l}90.60 \\
\pm 5.92\end{array}$ & $\begin{array}{l}84.96 \\
\pm 2.72\end{array}$ & $\begin{array}{l}86.96 \\
\pm 2.79\end{array}$ \\
\hline$\geq 30(n=184)$ & $\begin{array}{l}94.27 \\
\pm 4.49\end{array}$ & $\begin{array}{l}84.23 \\
\pm 3.83\end{array}$ & $\begin{array}{l}89.97 \\
\pm 9.17\end{array}$ & $\begin{array}{l}75.59 \\
\pm 7.36\end{array}$ & $\begin{array}{l}86.23 \\
\pm 2.52\end{array}$ & $\begin{array}{l}89.58 \\
\pm 2.52\end{array}$ & $\begin{array}{l}84.32 \\
\pm 3.42\end{array}$ & $\begin{array}{l}83.16 \\
\pm 2.89\end{array}$ \\
\hline $\begin{array}{l}\text { t-value } \\
\text { p-value }\end{array}$ & $\begin{array}{l}0.579 \\
0.565\end{array}$ & $\begin{array}{l}0.143 \\
0.887\end{array}$ & $\begin{array}{l}-1.116 \\
0.265\end{array}$ & $\begin{array}{l}1.605 \\
0.110\end{array}$ & $\begin{array}{l}0.655 \\
0.513\end{array}$ & $\begin{array}{l}0.362 \\
0.718\end{array}$ & $\begin{array}{l}0.190 \\
0.849\end{array}$ & $\begin{array}{l}2.061 \\
0.040 *\end{array}$ \\
\hline \multicolumn{9}{|c|}{ Frequency of ANE (days per week) } \\
\hline$<5(\mathrm{n}=203)$ & $\begin{array}{l}96.96 \\
\pm 0.16\end{array}$ & $\begin{array}{l}81.84 \\
\pm 5.97\end{array}$ & $\begin{array}{l}88.49 \\
\pm 9.24\end{array}$ & $\begin{array}{l}75.93 \\
\pm 7.53\end{array}$ & $\begin{array}{l}86.42 \\
\pm 2.33\end{array}$ & $\begin{array}{l}88.87 \\
\pm 1.25\end{array}$ & $\begin{array}{l}83.92 \\
\pm 3.03\end{array}$ & $\begin{array}{l}83.91 \\
\pm 2.77\end{array}$ \\
\hline$\geq 5(n=87)$ & $\begin{array}{l}95.24 \\
\pm 4.27\end{array}$ & $\begin{array}{l}89.33 \\
\pm 7.68\end{array}$ & $\begin{array}{l}89.65 \\
\pm 1.39\end{array}$ & $\begin{array}{l}77.33 \\
\pm 8.72\end{array}$ & $\begin{array}{l}86.40 \\
\pm 2.61\end{array}$ & $\begin{array}{l}91.31 \\
\pm 6.39\end{array}$ & $\begin{array}{l}86.14 \\
\pm 3.06\end{array}$ & $\begin{array}{l}84.05 \\
\pm 3.11\end{array}$ \\
\hline t-value & 0.248 & -1.965 & -0.314 & -0.634 & 0.015 & -1.013 & -0.783 & -0.086 \\
\hline $\mathrm{p}$-value & 0.805 & 0.500 & 0.754 & 0.526 & 0.988 & 0.312 & 0.434 & 0.931 \\
\hline
\end{tabular}

Table 5: Spearman rank correlation order showing correlations between participants' health-related quality of life and each of practice and patterns of antenatal exercises.

\begin{tabular}{|c|c|c|c|c|c|c|c|c|}
\hline & PF & RLPH & RLEP & EF & EWB & SF & PAIN & GH \\
\hline \multicolumn{9}{|c|}{ Practice of ANE } \\
\hline R-value & -0.080 & -0.043 & 0.003 & -0.102 & 0.067 & -0.067 & -0.054 & -0.161 \\
\hline p-value & 0.137 & 0.419 & 0.949 & 0.058 & 0.208 & 0.212 & 0.318 & $0.003 *$ \\
\hline \multicolumn{9}{|c|}{ Duration of ANE } \\
\hline R-value & 0.084 & 0.003 & 0.076 & -0.101 & -0.032 & -0.056 & -0.024 & -0.145 \\
\hline p-value & 0.160 & 0.956 & 0.202 & 0.090 & 0.595 & 0.351 & 0.688 & $0.015^{*}$ \\
\hline \multicolumn{9}{|c|}{ Frequency of ANE } \\
\hline R-value & 0.108 & 0.090 & 0.022 & 0.036 & 0.003 & 0.076 & 0.077 & 0.013 \\
\hline p-value & 0.070 & 0.128 & 0.716 & 0.551 & 0.959 & 0.202 & 0.196 & 0.832 \\
\hline
\end{tabular}

*represents $\mathrm{p}<0.05$; PF- physical functioning; RLPH- role limitation due to physical activity; RLEP- role limitation due to emotional problem; EF- energy and fatigue; EWB- emotional wellbeing; SF- social functioning; PAIN- pain; GH- general health; ANE- antenatal exercise

\section{DISCUSSION}

This study assessed the influence of antenatal exercise (ANE) on postpartum health-related quality of life (HRQOL) of women in Enugu, Nigeria. The study found a high prevalence of engagement in ANE among the women. This finding corroborates previous studies which reported high prevalence of ANE among pregnant women in western Nigeria. ${ }^{8,25}$ However other studies had reported low physical activity levels among pregnant women in Nigeria and other African countries. ${ }^{29,30}$

The high rate of ANE practice among pregnant women in the present study and others is an indicator of ongoing maternal health promotion and education interventions as well as suggestive of acceptance of modern antenatal care practices by women in Nigeria. The present study showed that pregnant women predominantly engaged in aerobic 
exercises. Mbada et al also reported same trend among pregnant women in western Nigeria. ${ }^{25}$

It is common practice for midwives/ nurses to engage pregnant women in mild aerobic exercises before commencing daily antenatal care in most Nigerian clinical settings. As a result, women who are interested in ANE usually imbibe the practice of aerobic exercises which they have been carrying out in the clinics. Relative to ANE frequency, the present study revealed that majority of the participants exercised for less than five days weekly which is below the standard recommendations of ANE practices. ${ }^{2}$ However, majority of the women exercised in line with standard recommendations of $\geq 30 \mathrm{mins}$ daily. Despite the high prevalence of ANE practice among these women, there is need for further education on the other available types of beneficial exercise regimes as well as the recommended frequency and duration of practices, provided there are no medical constraints.

Comparisons between the postpartum HRQOL of participants, relative to their practice and patterns of ANE showed that there was a significant difference in the general health domain of women who exercised and those who did not, with non-exercisers showing better scores in this domain. It was also observed that women who exercised for $<30$ mins daily also showed a significantly higher HRQOL scores in the general health domain, as compared to those who exercised for $\geq 30 \mathrm{mins}$ daily. Additionally, there were significant negative correlations between the general health of the participants and each of practice and duration of ANE. These results were contrary to the authors' expectations in that it was expected that practice and suitability of ANE would result to improved HRQOL.

Despite the fact that studies had shown positive correlations between ANE and antenatal HRQOL, there are only few empirical evidences to support the effects of ANE practice on postpartum health outcome. ${ }^{12,31}$ Previous studies reported improved postpartum quality of life in women who exercised during pregnancy. ${ }^{13,21}$ The results of the present study are suggestive of unsuitable ANE practices among these women. This may be evident from the prescribers of ANE, as reported by these women. The limited role of physiotherapists who are professionally endowed in human body biomechanics, kinesiology and exercise therapy is inadequate for effective ANE practices and health-related outcomes. There is need for appropriate maternal education on ANE choices and practices. Despite the fact that this study was purposely intended to naturally observe the women's ANE practices without the researchers' manipulations, this study design may have contributed to the results which contradicted the authors' expectations. As such, participants' subjective self-reports were the only variables considered. It is therefore recommended that future research should investigate whether the observed differences and relationships between ANE practices and
HRQOL are causal or rather involve experimental designs.

\section{CONCLUSION}

The authors therefore concluded that prevalence of antenatal exercise practice among women in this study was high although the patterns of practice were relatively inadequate. Suitable practice, frequency and duration of ANE did not affect women's postpartum quality of life.

Funding: No funding sources Conflict of interest: None declared

Ethical approval: The study was approved by the University of Nigeria Health Research and Ethics Committee

\section{REFERENCES}

1. Artal R, O'Toole M. Guidelines of american college of obstetricians and gynecologists for exercise during pregnancy and the postpartum period. Br J Sports Med. 2003;37(1):6-12.

2. ACOG Committee on Obstetrics Practice. Exercise during Pregnancy and Postpartum period: Number 267. Int J Gynecol Obstet. 2002;77:79-81.

3. Nascimento SL, Surita FG, Cecatti JG. Physical exercise during pregnancy: A systematic review. Curr Opin Obstet Gynecol. 2012;24(6):387-94.

4. Wolfe LA, Davies GAL. Canadian guidelines for exercise in pregnancy. Clin Obstet Gynecol. 2003;46(2):488-95.

5. Ribeiro CP, Milanez H. Knowledge, attitude and practice of women in Campinas, $\mathrm{S}^{\sim}$ ao Paulo, Brazil with respect to physical exercise in pregnancy: A descriptive study. Reproductive Health. 2011;8:31

6. Mottola MF, Ruchat SM. Exercise guidelines for women with gestational diabetes. Gestational Diabetes. 2011;339-62.

7. Chasen-Taber L. Physical activity and dietary behaviours associated with weight gain and impaired glucose tolerance among pregnant Latinas. Adv Nutr. 2012;3:108-18.

8. Mbada CE, Adebayo OE, Adeyemi AB, Arije OO, Dada OO, Akinwande OA, et al. Knowledge and attitude of Nigerian pregnant women towards antenatal exercise: A Cross-Sectional Survey. Obstet Gynecol. 2014;1-8.

9. Davies GAL, Wolfe LA, Mottola MF, Mac Kinnon C. Joint SOGC/CSEP clinical practice guideline: exercise in pregnancy and the postpartum period. Can J Appl Physiol. 2003;28(3):329-41.

10. Wadsworth $P$. The benefits of exercise in pregnancy. J Nurse Practitioners. 2007;3(5):333-9.

11. Ross LE, McLean LM. Anxiety disorders during pregnancy and postpartum period: A Systematic Review. J Clin Psychiatry. 2006;6:1285-90.

12. Montoya AAV, Orozco BL, Aguilar de Plata AC, Mosquera EM, Ramirez-Velez R. Aerobic exercise during pregnancy improves health related quality of 
life: A Randomised Trial. J Physiother. 2010;56:2538.

13. Haas JS, Jackson RA, Fuentes-Afflick E, Stewart AL, Dean ML, Brawarsky P, et al. Changes in the health status of women during and after pregnancy. $\mathrm{J}$ Intern Med. 2005;20(1):45-51.

14. Gaston A, Prapavessis H. Tired, moody and pregnant? Exercise may be the answer. Health Psychol. 2013;28(12):1353-69.

15. Mahishale AV, Maria-Vlorica LPA, Pati HS. Effect of postnatal exercises on quality of life in immediate postpartum mothers: a clinical trial. J South Asian Fed Obstet Gynecol. 2014;6(1):11-4.

16. Bahadoran P, Tirkesh F, Oreizi HR. Association between physical activity 3-12 months after delivery and postpartum well-being. Iran $\mathbf{J}$ Nurs Midwifery Res. 2014;19(1):82.

17. Blum JW, Beaudoin CM, Caton-Lemos L. Physical activity patterns and maternal well-being in postpartum women. Matern Child Health J. 2004;8:163-9.

18. Strøm M, Mortensen EL, Halldorson TI, Osterdal ML, Olsen SF. Leisure-time physical activity in pregnancy and risk of postpartum depression: a prospective study in a large national birth cohort. J Clin Psychiatry. 2009;70(12):1707-14.

19. Ersek JL, Huber LRB. Physical Activity Prior to and During Pregnancy and Risk of Postpartum Depressive Symptoms. J Obstet Gynecol Neonatal Nurs. 2009;38(5):556-66.

20. Demissie Z, Siega-Riz AM, Evenson KR, Herrin, AH, Dole N, Gaynes BN. Physical activity during pregnancy and postpartum depressive symptoms. Midwifery. 2013;29(2):139-47.

21. Campolong K, Jenkins S, Clark MM, Borowski K., Nelson N, Moore KM, et al. The association of exercise during pregnancy with trimester-specific and postpartum quality of life and depressive symptoms in a cohort of healthy pregnant women. Arch Womens Ment Health. 2017;1-10.

22. Vernon MM, Young-Hyman D, Looney SW. Maternal stress, physical activity and body mass index during new mothers' first year postpartum. Women Health. 2010;50:544-62.

23. Poyatos-Leon R, Garcia-Hermoso A, SanabriaMartinez G, Alvarez-Bueno C, Caveno-Redondo I,
Martinez-Vizcaino V. Effects of exercise based intervention on postpartum depression: A metaanalysis of randomized controlled trials. Birth. 2017;44:200-8.

24. Songøygard KM, Stafne SN, Evensen KAI, Salvesen KÅ, Vik T, MØRkved SIV. Does exercise during pregnancy prevent postnatal depression? Acta Obstet Gynecol Scand. 2012;91(1):62-7.

25. Mbada E, Adebayo O, Taofeek O, Faremi F, Oginni M, Ogundele A, et al. Practice and pattern of antenatal and postnatal exercises among Nigerian women: a cross-sectional study. Int J Women's Health Reprod Sc. 2015;3(2):93-8.

26. Ware JE, Sherbourne CD. The MOS 36-Item Short Form Health Survey (SF-36®): I. Conceptual framework and item selection. Med Care. 1992;30(6):473-83.

27. Ware JE, Snow KK., Kosinski M, Gandek, B. SF36® Health Survey Manual 1993.

28. Mc Horney CA, Ware JE, Lu JFR, Sherbourne CD. The MOS 36- Item Short-Form health-Survey (SF36®): III. Tests of data quality, scaling assumptions and reliability across diverse patient groups. Med Care. 1994;32(4):40-66.

29. Adeniyi AF, Ogwumike OO, Osinike CI. Physical activity and energy expenditure: findings from the Ibadan Pregnant Women's Survey. Afr J Reprod Health. 2014;18(2):117-26.

30. Mukona D, Munjanja SP, Zvinavashe M, StrayPederson B. Physical activity in pregnant women in Africa: A systematic review. Int J Nurs Midwifery. 2016;8(4):28-34.

31. Arizabaleta AVM, Buitrago LO, de Plata ACA, Escudero MM, Ramírez-Vélez R. Aerobic exercise during pregnancy improves health-related quality of life: a randomised trial. J Physiother. 2010;56(4):253-8.

Cite this article as: Ojukwu $\mathrm{CP}$, Okemuo AJ, Okeke OG, Ikele CN, Uchenwoke CI, Anekwu EM.

Postpartum health related quality of life: relationship to antenatal exercise practice in a Nigerian population. Int J Reprod Contracept Obstet Gynecol 2018;7:2541-6. 